\title{
Affectivity and Teaching: The Marks of the Unforgettable Teacher
}

\author{
Sérgio Antônio da Silva Leite \\ Universidade Estadual de Campinas (UNICAMP), São Paulo, Brazil
}

\begin{abstract}
The present text is based on research involving high school students in Brazilian schools. It aims to analyze the affective dimension identified in pedagogical practices developed by teachers who have been considered unforgettable. Based on the theoretical framework of Wallon and Vygotsky, it is assumed that the learning process takes place as a result of the relationship established between the subject and the object of knowledge; such a process, however, is not direct, but mediated by social agents. Furthermore, it is also assumed that such relations do not merely involve the cognitive and motor dimensions, but also the affective dimension, characterized by the subjective impacts, either positive or negative, that every subject-object relation produces. In a classroom, the matter is related to the pedagogical mediation process developed by the teacher, which aims to enable the students to appropriate school contents: Depending on how it unfolds, movements in the subject-object relation are produced, which in their extremes, are characterized by situations of approximation (positive affective relations) or distancing (negative affective relations). Such processes will be constituted as parts of the students' subjectivity. In this text, the focus is on the pedagogical mediation practices of teachers considered unforgettable, as they allow movements of affectively positive approximation among students and their respective learning content. Research data allowed the creation of four major thematic categories: pedagogical practices developed in the classroom; the relationship between teacher and teaching object as perceived by the students; personal characteristics of the teacher; and changes observed in students. Therefore, these nuclei characterize the affective marks identified in the pedagogical practice which mediates the relation student-school content. These categories are discussed in the light of the theories underlying this study.
\end{abstract}

Keywords: learning, affectivity, pedagogical practices, teacher mediation

\section{Introduction}

The question of affectivity and its implications for education has been an increasingly discussed topic in the academic environment. Clearly, emotions and affections have always been objects of study of psychological theories, as pointed by Engelman (1978).

However, it can be reaffirmed that in Brazil, in the last two decades, a growing presence of studies focusing on affection has been observed in the research agenda of several scholars in the education sector, mainly from authors linked to psychology (Almeida, 1997, 1999; Dantas, 1992; Mahoney, 1993; Oliveira, 1992; Pinheiro, 1995; Casassus, 2003, 2009; Arantes \& Aquino, 2003; Vasconcelos, 2004; Leite, 2006; Ribeiro \& Jutras, 2006; Franco, 2009; Amado, Freire, Carvalho, \& André, 2009; Ribeiro, 2010).

Sérgio Antônio da Silva Leite, Ph.D., Faculdade de Educação, Universidade Estadual de Campinas (UNICAMP). 
In a survey sponsored by UNESCO, which analyzed the decisive factors for learning in school settings in various countries, Casassus (2009) found that the most important factor explaining the differences in learning was the emotional climate in the classroom. This factor consists of three variables: The first is the bond that is established between teacher and students; the second is the bond that is established among the students; and the third is the climate that arises from the first two variables. According to the author, the emotional climate in the classroom is the main factor that explains the variations in students' performance, which suggests that there is no learning outside the emotional space.

In the present text, we will discuss the affective dimension in teaching practices carried out in the classroom. It is assumed that the pedagogical mediation is also affective in nature and, depending on how it is developed, it produces an affective impact (either positive or negative) on the relationship established between the students and the various school subject areas/content. Such impacts are characterized by the subject/student affective movements of "approximation" or "distancing" in relation to the objects/school content.

Based on research reports, we will discuss some pedagogical decisions that teachers take when they plan and develop their courses, indicating the possible affective impact on students.

\section{Reason-Emotion: Dualist Conceptions $\times$ Monist Conceptions}

One of the theoretical challenges is to understand the reasons why the concept of affectivity remained historically peripheral in teaching-learning relations. One can assume that this is due, at least partly, to the secular predominance of the "dualistic conception", in which man is seen as being split between reason and emotion. Accepting such division implies assuming that man is a being who either thinks, or feels, with no relationship between these two dimensions. Moreover, one faces the problem that the dualistic thinking poses to science: Man would present a dimension which would be out of reach for a scientific approach, which means assuming that scientific knowledge can never entirely explain the human phenomenon.

On top of that, in the case of the duality reason $\times$ emotion, for centuries the dominant thought not only has assumed dualism, but has also elected reason as the superior dimension which best characterizes man, to the point of deeming emotion as the dark and nebulous side of human nature: Therefore, the control/mastery of emotions would be a function of reason.

The hierarchical domain of reason over emotion is observed in different historical periods: in ancient times, by the opposition between intelligible knowledge (subject to an objective approach) and sensitive (non-scientific) knowledge, as feelings were not considered passive to objective knowledge due to their degree of subjectivity. In the Middle Ages, by the conflict between reason and faith, there is the predominance of the first over the latter. In modernity, by the Cartesian dualism, although there has been a growing appreciation of the individual as a thinking being, carrying an individual consciousness and freedom. In the historical sequence, we understand that the apex of the rationalist predominance occurred in the late nineteenth century with Auguste Comte's ${ }^{1}$ positivism, ratifying that knowledge is only possible through reason ${ }^{2}$.

The secular influence of the dualistic conception in practices in educational institutions is undeniable: Western society inherited a conception according to which the educational work must be essentially directed to the development of cognitive aspects, centered on reason. Thus, affectivity should not be involved in this process. In this sense, curricula and programs developed in different moments of the Brazilian educational

\footnotetext{
1 1789-1857.

2 Analysis of these questions can be found in Marcondes (2000), Bosch (1998), Figueiredo (1992), and Giles (1993).
} 
policy focused on the development of the rational-cognitive dimension - through the pedagogical work in the classroom, at the expense of the affective dimension.

With the development of science and research in the various areas of knowledge, conditions have been created that allowed the construction of a more adequate theoretical model, which permitted to understand that reason and emotion are inseparable, holding an intimate relationship. These aspects have created the conditions for the emergence of the "monistic conception" of human constitution, which gained strength in the 20th century. With the advent of philosophical, sociological, and psychological theories centered on cultural, historical, and social determinants of the process of human constitution, the groundwork for a new way of understanding man and the very relationship between reason and emotion was laid. The philosophical and scientific thought about man thus turned toward a monistic conception, in which affectivity and cognition come to be interpreted as inseparable dimensions, and analyzing them separately is no longer possible.

One of the philosophers whose thought played a key historical role in the process of overcoming the dualistic conception was Baruch Spinoza ${ }^{3}$ (Spinoza, 2009; Chauí, 2005; Damásio, 2001, 2003), who stands out not only by the content of his ideas, but for the very period they were produced and disseminated —at the heart of the 17 th century!

Spinoza argued that body and mind are attributes of a single substance, which implied assuming that body and soul follow the same laws, thus breaking with the secular hierarchy that situated the soul as a superior instance in relation to the body.

One can illustrate the radical change in relation to how man is conceived by contrasting two maxims, elaborated in an interval of three and a half centuries: On the one hand, the Cartesian maxim ${ }^{4}$ "I think therefore I am", , according to which reason/thinking is interpreted as the grounds for existence; on the other hand, the recent maxim of the neurophysiologist Antonio Damasio "I exist and I am, therefore I think" (Damasio, 2001), proposing a clear inversion of the secular domination of reason over emotion, declaring that this is the basis for the constitution of man's cognitive structure - a similar position was also taken by Henri Wallon.

\section{The Affection Group}

In the 1990s, a research group called "The Affection Group"6 was created and since then it has been carrying out studies and research work on the subject ${ }^{7}$. This group, under the coordination of this article's author, gathers supervised doctoral, masters', and undergraduate research.

The studies carried out by the Affection Group focus on the so-called "qualitative approaches" (Ludke \& André, 1986; Bogdan \& Biklen, 1994). According to these authors, qualitative research is an umbrella term that includes numerous research strategies that share common characteristics: Qualitative data must be rich in descriptive detail, in order to investigate the phenomena in all their complexity and in their natural environment.

\footnotetext{
3 1632-1677.

${ }^{4}$ Descartes, 1596-1650.

5 The work of Descartes "Discourse on the Method" was published in1637.

${ }^{6}$ The Affection Group (Grupo do Afeto) is part of the research group ALLE (Alfabetização Leitura Escrita), from the Education Faculty at UNICAMP.

${ }^{7}$ So far, under the theme Affectivity, the group counts with two doctoral theses, six master's theses and 14 undergraduate research work, totalizing 22 research projects. All of them under our supervision.
} 
In this particular case, a factor that undoubtedly facilitated the group's involvement with the research was the increased contact with the data collection procedures, called "recurring interviews" and "autoscopy" (Leite \& Colombo, 2006).

Autoscopy is a procedure of data collection known as "self-confrontation on screen": Recordings sessions of the subject's behavior (e.g., relationships in the classroom) are held, and after the tape is edited, the subject is asked to watch the recorded material in which he/she appears, being verbally encouraged by the researcher to make comments according to the objectives of the research. The primary data are the verbal accounts of the subject while watching their images on the TV screen.

Recurring interviews, on the other hand, is a procedure for collecting and analyzing data that requires an intense interactive process between the researcher and the subject(s), as the researcher participates in the initial phase of the data analysis process, which occurs simultaneously with the data collection process, performed by means of several interviews.

Most of the research carried out by the Affection Group studied the pedagogical mediations planned and developed by teachers. The texts published by Leite (2006) represent an important milestone in disclosing the work of the group and are targeted at educators and students with an interest in the subject.

It is possible to identify three core areas that have guided the work of the Affection Group: affection in the teacher-student-student interpersonal relations; the process of constitution of the subject as a reader; and affectivity in pedagogical practices, planned and developed by teachers in the classroom. This text will focus on the last aspect.

After the first research papers on the subject, mainly focusing on the interpersonal relationships in the classroom, it soon became obvious that the affective dimension goes beyond the limits of dermal relations and face-to-face contacts. Initial studies on the "unforgettable teacher" (Falcin, 2003; Tagliaferro, 2003) clearly showed that all decisions planned and executed by teachers produce strong emotional impact on students, even when teachers are not physically present in the situation, as occurs in face-to-face relationships. This has led the group to broaden the scope as to include pedagogical practices/mediations, specifically involved with teaching conditions, trying to identify and analyze the impact that they produce in the relations established between students/subjects and their respective school content/objects addressed in the classroom. Thus, the focus of research on the affective dimension became, specifically, the processes of teaching and learning that occur in the classroom.

\section{Theoretical Foundations}

To better explore the subject of affection and its impact on the teaching/learning process, it is of ultimate importance to construct an adequate theoretical model; one that allows us to comprehend the relationship between reason and emotion transcending the traditional view or common sense as already discussed. A theoretical model that helps us to understand that man is a unique being; that dualism is an artificial reading of the human constitution, produced by man himself under certain historical, political, and social conditions; that, in fact, human beings simultaneously think and feel, which enables us to understand that emotion is always present in the relationship between man and culture; that, therefore, reason and emotion are inseparable, which points to a "holistic/monistic" conception of the human constitution. Anyhow, this is a theme that requires study and the practice of reflection on it, since these questions often clash and collide with old ideological conceptions (of a liberal nature), many of them still strongly present in the very constitution of our subjectivity. 
The set of theoretical assumptions, present since the beginning of the work with the Affection Group, has been gradually consolidated, as new research has been conducted. Such assumptions have been established based on two great theorists of contemporary psychology: L. S. Vygotsky and H. Wallon.

Therefore, in the field of psychological theory, the research carried out by the Affection Group was anchored on authors who share theories whose assumptions are centered in the dialectical materialism conception. According to this concept, the process of human development and, therefore, of the higher psychological functions that characterize man, must be explained by the relationship that man holds with their culture, in their social environment.

For these authors, the goal of a psychological theory is to explain the mechanisms by which natural/phylogenetic processes, present in newborn, are mingled with the cultural and social processes to produce the complex functions that characterize the mature man.

Wallon $(1968 ; 1978 ; 1995)$ developed a theory about the process of human development centered on the relationship between four major "functional cores" determinants of the process: affection, cognition, motor act and person. For the author, the development process, which occurs through the continuous interaction between these nuclei, can only be explained by the dialectical relationship between biological/organic processes and the social environment - that is, the biological and the social processes are inextricably linked and are always dialectically related.

For Wallon (1968), emotions are expressions of subjective states, but with organic components (muscle contractions, visceral contractions, etc.). Thus, in the wallonian theory, emotion is the first and strongest bond that is established between the subject and the people in the environment, constituting the initial manifestations of subjective states, with organic components. It has three properties: (1) contagiousness - the ability to contaminate others; (2) plasticity - the ability to reflect its signals onthebody; and (3) regressiveness - the ability to regress reasoning activities. For the author (Wallon, 1971), it is up to the emotional manifestations, through their power of contagion, to enable the newborn to sensitize the people in the environment to satisfy their needs and desires.

Affectivity, in turn, involves a wider range of manifestations, encompassing emotions (of biological origin) and feelings (psychological in origin). In this sense, it is a broader process, involving emotion, feeling, and passion. According to Mahoney (2004), "Emotions are identified by their organic, empirical and short duration side; the feelings, more by the representational and longer duration component... Passion is hidden, longer lasting, more intense, more focused and has more self-control over behavior" (p. 17).

Thus, affectivity is a broader concept, being constituted later in the process of human development, involving experiences and more complex forms of expression, developing through the appropriation, by the individual, of the symbolic processes of culture that will enable its representation. It is a concept that "besides involving an organic, bodily, motor and plastic component, which is the emotion, also has a cognitive, representational component, which are the feelings and passion" (Dér, 2004, p. 61). It should be noted, however, that the complexification of the forms of affective manifestations - that some authors characterize as cognitivization of the affective development process - can only be achieved through cultural mediation, hence, within a social environment (Dantas, 1992).

Thus, emotion and cognition coexist in the individual at all times, although at different stages of development, as Wallon argues, there is an alternating predominance of one over the other. As Almeida (1999, p. 29) points out, "Intelligence does not develop without affectivity, and vice versa, as both comprise a unity of opposites". 
Vygotsky (1993; 1998), in turn, similarly assumes a position according to which the individual is born as a biological being, the result of the phylogenetic history of the species, but by being inserted into the culture, will be constituted as a socio-historical being. That is, the human being is born with the so-called "elementary functions", of biological nature. It is for the psychological theory to explain how such functions, being affected by cultural insertion, will be constituted into the so-called "superior functions", which characterize the human being.

Oliveira (1993) summarizes the fundamental ideas of Vygotsky's theory: (1) The higher psychological functions have biological support because they are products of brain activity: The brain, taken as the biological basis of psychological functioning, is understood as an open system with great plasticity, allowing the immense possibilities of human achievement and man's enormous capacity to adapt; (2) The psychological functioning is based on the concrete social relations between the individual and the outside world, which develop in a historical process; thus, the higher functions are constituted in/by culture; and (3) The man-world relation is always mediated by symbolic systems, which means that the concept of mediation is the central construct of the theory. Among the symbolic systems, language (with emphasis on speech) is considered fundamental for the construction of the superior functions, being internalized in the first years of the process of development and later acting as an instrument of thought.

Human development can be understood as a process of appropriation of cultural elements and processes, occurring from the external plane (interpersonal relationships) to the internal plane (intrapersonal relationships), mediated by the actions of others (individuals or cultural agents). Therefore, learning plays a crucial role in that it enables the development process.

There is no denying the impact of these concepts in pedagogical thinking. On the one hand, it points out that the process of pedagogical mediation is fundamental in the relationship that is established between the subject/student and the object of knowledge/school content, remembering that, in the classroom, the teacher is the main mediator agent, although not the only one. On the other hand, it suggests that the pedagogical mediation occurs by means of concrete practices and situations, which means that they can be planned as to increase the chances of successful learning by the student, who, in turn, is understood by Vygotsky (1998) as an "interactive subject", who plays an active role in the interaction processes they experience.

Regarding affection, Vygotsky (1993) condemns the historical division between affection and cognition, remarking that this was one of the great problems of psychology in his time, while criticizing the organic approaches. For the author, emotions move from the initially biological, individual plane to a plane of upper, symbolic function of meanings and senses, constituted in/by culture. In this process, the meanings and senses assigned to the cultural objects and functions by culture and the individual himself, based on the lived experiences, are internalized. In this process, the role of the other, as a mediator agent between the subject and the cultural objects, is crucial. Thus, for the author, "The emotions isolate themselves increasingly from the realm of instincts and move to a whole new level" (Vygotsky, 1998, p. 94).

Comparing the positions of Wallon and Vygotsky on affectivity, it can be seen that the authors have points in common in relation to the essential aspects of the phenomenon in question: (1) They both assume a developmental conception of emotional manifestations: Initially organic, they gain complexity as the individual, who is inserted in culture, develops and starts to act in the symbolic universe, which makes them expand and become increasingly more complex; (2) Therefore, they both assume the social character of affectivity; and (3) They assume that the relationship between affectivity and intelligence is foundational to the process of human development. 
Following is a synthesis of the ideas that underlie the research work developed by the members of the Affection Group:

(1) The production of knowledge is a process that occurs based on the relationship that is established between the subject and the object. In this relation, the subject's participation is essentially active, that is, the relationship with the various objects allows the subject to elaborate ideas, hypothesis, relations, analysis, synthesis, etc.. Such processes, at school, correspond to the relationships that are established between the student and many and varied contents being addressed;

(2) Every subject-object relation is always mediated by cultural agents, which can be individuals or cultural products, as is the case of a text written by someone, which enables the contact between the subject/subject matter. Besides that, one can assume that the way the mediation process will be carried out is one of the main determinants of the quality of the relationship that will be established between the subject and the respective object. At school, the main mediator agent between the subject (student) and the object (school content), is, undoubtedly, the teacher, in so far as all pedagogical practices depend on his/her planning and concrete manner in which they are put into practice;

(3) The relations established between subject-object-mediator are also markedly affective. That means to say that such relations do not solely involve the cognitive sphere, but, simultaneously, evoke internal and subjective repercussions in the subjects, which are basically affective in nature;

(4) Finally, as an inevitable consequence of the assumptions stated above, it is assumed that the quality of the mediation is one of the main determinants of the relationship that will be established between the subject and the object of knowledge, involving, simultaneously, the cognitive and affective dimensions. In other words, the kind of affective relationship that will be established between the student and a particular school content—a relationship that can vary between strong movements of "approximation" or "distancing", that is, relations of "love or hate", in their extremes - will depend, to a large extent, on the concrete practices of pedagogical mediation planned and implemented in the classroom by the mediation agents, which means to say that the pedagogical mediation practices are also markedly affective.

The information gathered during all these years, by means of the studies developed in the Affection Group allow us to presuppose that, when the pedagogical mediation enables the students to successfully appropriate (or take ownership of) the object in question - which characterizes successful learning - and more than that, when such success is perceived by the student - that is, the student is aware of the process - the chances of establishing a positive affective bond of "approximation" between the student and the object/school content being addressed are enhanced. This way, the positive approximation between the student and the subject matter he/she studied depends, in great measure, on the awareness that the student develops in relation to the success of his/her learning process.

It is worth noticing that the opposite situation — school failure - can also be explained by the same theoretical model exposed above. Such concept is frequently analyzed in terms of school dropout and failure rates. However, from an affective point of view, it corresponds to pedagogical mediation processes, whose final product is generally marked by a negative affective relation - movement of "distancing"- between the subject and the object in question.

In this sense, research should aim to describe and analyze the pedagogical practices implemented in the classroom (including the mediation processes that occur out of this specific physical space) which favor, mainly, the establishment of affective approximation relations between the subject/student and the objects/school 
contents. It is understood that the concept of pedagogical mediation is related to the relations which are concretely established and experienced in the classroom and which can be accessed by the scientist, obviously by means of methodology that is adequate to the characteristics of the phenomenon in question.

Likewise, it is also the objective of the research to identify the pedagogical relations that produce the situations of distancing between the subject-object, characterized by the affectively negative impacts on the students.

\section{Affetivity and the Unforgettable Teacher}

In the early years of the 21st century, the studies carried out by the Affection Group started to focus on the question of the unforgettable teacher as an object of study, as a strategy to deepen the analysis of affectivity in pedagogical practices. Based on accounts of several university students, who acknowledged the existence of an unforgettable teacher in their lives, whom, in certain cases, had determined the very professional choice of those subjects, the profile of such professional was defined as being the teacher who develops a pedagogical practice considered successful. On the one hand, they enable the students to adequately take ownership of the contents addressed in the classroom and, simultaneously, allow them to approach those contents in a positive affective manner. In other words, the unforgettable teacher develops a pedagogical practice that enables both learning and the positive affective involvement of the students with the contents developed in the classroom.

The definition of this profile was important, since earlier studies, carried out by the members of the Affection Group, point out that, in the traditional teaching model, still very present in Brazilian schools, the study behavior developed by the students can be characterized more like processes of dodging from undesired situations: The students normally study to avoid low grades, parents' punishment, etc.- negative affective consequences, and not because they are affectively involved with the contents in question. Such affective movements of approximation or distancing are basically determined by the pedagogical practices developed by the teacher.

The studies conducted on pedagogical mediation of the so-called unforgettable teacher (Falcin, 2003; Tagliaferro, 2003; Leite \& Tagliaferro, 2005; Leite \& Falcin, 2006) involved young people attending the last year of high school in Brazilian schools, who were getting prepared to enter university. Such studies were qualitative in nature and the data were collected by means of recurrent interviews (Leite \& Colombo, 2006). In this procedure, the subjects actively participated in the process of analysis, commenting and making suggestions regarding the thematic nuclei constructed by the researcher during the process. This procedure involves a series of interviews, and in the first one, the research main objective was presented to the subject. In the present case, the question was: "Of all subjects you have studied, was there any teacher/professor who has positively impacted your life?"

After each interview, the researcher analyzed the accounts generated by the interview and elaborated a set of thematic nuclei and sub-nuclei, based on the subjects statements. It was inferred that such nuclei/sub-nuclei corresponded to possible aspects of the teacher's pedagogical practice, related with the presence of the affective dimension, that is, pedagogical practice aspects which had probably produced positive affective impacts on the relationship between the student and the contents in questions. Those nuclei/sub-nuclei were then presented in the beginning of the following session, when the student was asked to further discuss, alter, or broaden the scope of the comments, etc.. The process of interviews was repeated several times, only being interrupted when the subject and the interviewer agreed that the theme had been fully covered. After that, the researcher would 
complement the data analysis with the final nuclei and they were all then discussed under the light of the theoretical assumptions previously discussed.

Data from such research allows the identification, through the process of analysis of the subjects' statements, of four major thematic nuclei, which correspond to the main characteristics of the pedagogical practice developed by the unforgettable teachers:

(1) Pedagogical decisions and practices developed in the classroom. This nucleus refers to the practices effectively put into practice by the teacher, in the classroom. According to the data collected during the interviews, the teachers in question had developed their teaching practices aiming, fundamentally, at the students' learning success. This can be identified, for example, in the following aspects:

a. careful choice of teaching objectives, so that students can identify their relevance and importance to the educational process; besides that, the objectives are clearly defined;

b. decisions on how to start the teaching process based on what the learners already master regarding the content to be worked on; this implies that the unforgettable teacher starts the process after a brief assessment, either formal or informal, aiming to access what the learners already know about the topic;

c. choice of teaching activities as to assure a high level of motivation from the students; besides that, the instructions are always clear and there is constant adequate feedback from the teacher in relation to the students' performance; on top of that, the learners tell that the unforgettable teacher's posture in the classroom is always positive, seeking to encourage them, especially in face of difficulties;

d. use of a wide range of materials, not being restricted to just one source, such as a specific textbook; data show that the unforgettable teacher makes it possible for the students to access different sources of information on the various topics being approached;

e. assessment practices which allow, whenever possible, that their results be used as to favor the students' learning process; thus, when negative results or problems are detected, the unforgettable teacher usually reviews the content which had been covered, reorganizing the pedagogical practices by means of more appropriate strategies, before the students are assessed again;

f. physical organization of the classroom as a function of the specific objectives of the moment, i.e., the classroom architecture is often changed to meet the teaching goals. Clearly, this list does not exhaust the aspects identified in the speech of students, but what stands out in this nucleus is that the unforgettable teacher is always demanding when it comes to the students' performance; however, he/she seeks to create all necessary pedagogical conditions for their learning process to be successful.

(2) The relation teacher-object of knowledge: This nucleus gathers the students' statements which are related to how they perceive the relation between the teacher and the contents of the subject they teach. Two aspects are highlighted in this nucleus:

a. the students acknowledge that the unforgettable teacher shows a broad knowledge of the subject area he/she teaches; that is, the students notice that the teacher fully domains the knowledge area in question, which seems to lead to feelings of safety and admiration from the students;

b. the most relevant aspect in this nucleus, however, refers to the fact that the students acknowledge that there is a clear relation of passion between the teacher and the content taught; this relation is fully detected when the students describe the lectures given by the unforgettable teacher: What amazes them is noticing this deep passion the teacher has with the teaching area, which suggests that this feeling is contagious, as Wallon (1968) had already pointed out in relation to one of the main characteristics of emotion: its power of contagion. 
In this sense, one can understand the fact that the students indicate the teacher's lectures as the most important pedagogical practice developed by the unforgettable teacher in the classroom: Besides being always carefully planned, this would be the space where the passion relations between the teacher and the teaching contents were experienced and shared with the students.

(3) Other aspects of the unforgettable teacher's behavior: This nucleus gathers students' statements that indicate two major characteristics of the referred teacher:

a. one of the aspects mentioned by virtually all of the subjects who have been interviewed was his/her constant availability with respect to students. They always recognized that the unforgettable teacher was receptive to the students, who, as a result, saw him/her as a professional they could trust;

b. a second aspect identified during the interviews is related to the fact that the teacher seeks to help students develop a critical stance in relation to the topics or themes approached in class. This was perceived when the teacher continuously presented different theoretical positions in relation to the content addressed. This does not mean a neutral position, but a strategy to foster debate and a critical stance from the students, through the confrontation of ideas and by enhancing their argumentative ability.

(4) Effects on the future lives of the students: This last nucleus gathers the statements related to the impacts that the teaching process, developed by the unforgettable teacher, has on the students. Here, two aspects are also highlighted:

a. the students showed great personal change, of cognitive and affective nature, in relation to the content studied with the referred teacher: Many mentioned that at first they even had a negative reaction in relation to the subject matter, but all of them recognized that they started to value the objectives and content studied, due to the work developed by the teacher;

b. some students reported that these positive impacts were so relevant that they ended up directing their professional choices: They started planning and seeking careers related to the teaching area of the unforgettable teacher they had contact with.

The analysis of the four nuclei, which characterize the unforgettable teacher by their students, reaffirms the theoretical assumption assumed by the Affection Group: The quality of the pedagogical mediation developed by these teachers has determined, to a large extent, the quality of the relation that was established between the students and the contents covered during the teaching-learning process that was experienced with that teacher. The data clearly indicate that the students are highly affected by: (1) the passion the teacher demonstrates for the teaching object; (2) the content knowledge the teacher possesses; and (3) the pedagogical decisions and practices developed by the teacher, always coherent with the aim and commitment of assuring successful learning.

What seems to underlie the students' affective development process are the environmental conditions, provided by the teacher, that allow the students to successfully appropriate the contents and be aware of the process - The students state that they gradually developed a feeling of being able to learn, a sense of confidence, which can be characterized as a feeling of positive self-esteem, or of self-efficacy, as proposes Bandura (2005).

\section{Affectivity in the Pedagogical Decisions}

The studies carried out by the Affection Group (Leite \& Tassoni, 2002, 2007; Leite \& Tagliaferro, 2005; Leite, 2006; Leite \& Falcin, 2006; Leite \& Kager, 2009) allow the identification of some of the decisions assumed by a teacher when planning and developing their teaching conditions, which, if adequate, increase the 
odds of affectively impacting the relationship between the students and the content addressed in a positive way. Obviously, we do not refer to a specific teaching methodology here, but reinforce that, regardless of the theoretical standpoint assumed by the teacher, in all planned teaching situations he/she takes some decisions that, in their practical development, will have inevitable affective consequences for the relationship established between the student and the specific teaching content, as previously discussed.

It is possible to identify some of these decisions and their possible impacts. Even acknowledging that there are innumerous other factors that compose the pedagogical mediation process, we intend to highlight five decisions, identified through the information gathered by the Affection Group's studies. Those are: (1) the choice of teaching objectives; (2) the decision regarding the beginning of the teaching process; (3) the organization of the teaching content; (4) the choice of teaching procedures and activities; and (5) the choice of assessment procedures.

The following is a summary of each one of these decisions that were pointed out:

(1) The choice of teaching objectives:

The choice of teaching objectives is a decision that always reflects the values, beliefs, and conceptions of those who choose or select them, be that a group of educators, an instance of a public body, or an isolated teacher.

The affective dimension in relation to the teaching objectives refers to their relevance, recognized by a certain group of students or by a subject. The problem arises when the student does not identify the relevance of the proposed objectives, be it for his life, for the society he lives in, or for his professional future. In this sense, most of the teaching objectives of the traditional school have been pointed out as irrelevant, from the student standpoint, which certainly contributes to the construction of a school divorced from reality. That does not mean that teaching should be basically pragmatic, but it can be assumed that the knowledge currently accumulated in several areas can allow individuals better conditions for the exercise of citizenship and social insertion in a critical and transforming perspective.

Therefore, it is important for the school to select objectives and content that is perceived as relevant by the students, thus increasing the chances of positive affective bonds being formed between the students and the objects in question.

However, it is important to remember that the inverse relation can also be true: Bureaucratic teaching, with objectives whose relevance is not understood by the students, can collaborate to the movement of distancing in the relationship that is going to be established between the subject and the object in question. Evidently, that question is related to the school's pedagogical project, including the specific objectives of each curricular area. Such project must be the fruit of the collective reflection done by the school's faculty, a process in which the matter of relevance of the teaching goals and contents must be the object of continuous discussion and evaluation.

(2) The decision regarding the beginning of the teaching process:

The studies available on this topic, conducted by the Affection Group, suggest that to initiate the teaching process based on what the student already knows about the encompassed contents increases the chances of the student's learning process to succeed. As we have seen, such success has undeniable affective implications involved.

The inverse relation can also take place, being frequently observed in schools: When the teacher decides to initiate his teaching programme too far beyond the student's current knowledge background, a situation 
develops, in which the odds of failure increase soon after the teaching-learning process begins. With that, the possibilities of establishing a positive affective relationship between the student and the content in question deteriorate prematurely.

The problem of lack of previous knowledge, necessary for the student to start studying from the point defined by the teacher, has been traditionally brought up by other authors. Ausubel (1968), for instance, already defended that among the factors that influence learning, one of the most relevant is related to the student's previous knowledge.

The main pedagogical implication of this decision suggests that the starting point of teaching must be defined only after the teacher conducts a brief diagnostic evaluation on the content that is judged as essential, so the student can have the means to begin the studies from a specific learning point. If the student does not display that knowledge, it is imperative that the teacher or the institution foresee conditions for her/him to appropriate the necessary knowledge, thus decreasing their chances of premature failure and the consequent negative affective relationship with the object in question.

(3) The organization of the teaching content:

When the course content is organized in a random fashion, not taking the organization logic of the knowledge area into consideration, the process of appropriation of such content is hampered. This is the case when the teacher does not adequately analyze the teaching objectives neither identifies the content involved or the way in which the concepts and principles of a specific area are interrelated. Some data from the research undertaken by our group suggest that the lack of logical organization of the content of a given course can increase the possibilities of students' failure, contributing to the foreseen deterioration of the affective relationship between the student and the object in question. Organizing the content in a proper way thus seems to be related with the fact that the teacher respects the epistemological organization of the respective teaching area; that is, the teacher does not teach the whole content at once and, as the student also does not learn this way, it is necessary to organize the content, sequencing and delimitating it in each teaching step. It is possible that the difficulties in analyzing objectives - generally by lack of knowledge from the teachers-partially explain the frequent use of the textbook as the main teaching resource. However, other factors may also be involved.

(4) The choice of teaching procedures and activities:

The choice of teaching activities concerns the relations that will effectively take place in class-If the teacher is going to give a lecture (and how this will be done), if there will be group work, if he/she will propose the reading of a text, if they will go on a field trip, etc.. To sum up, it is the observable relations, generally with immediate effects identified in the situation itself, which must be in line with the proposed objectives. In this sense, the implication of the affective dimension in each activity which is planned and developed is undeniable. Activities which are well chosen and adequately developed undoubtedly increase the chances of successful learning and the consequent affective relation of approximation between the student and the content. This fact might explain the preference for this item in most of the research conducted by the Affection Group.

On the other hand, the choice of teaching procedures and activities present innumerous challenges that can transform such choices in real conditions of failure for the student: That is the case, for instance, of the inadequate choice of an activity in view of the proposed objective. It is common to see teaching activities which are not related to the expected specific objectives; this fact is reinforced when the assessment activities are radically different from the activities used by the teacher. Or yet, the development of a totally demotivating 
activity, even when relevant objectives are presented. Young students are normally very perceptive and can identify whether a teaching activity is adequate in view of the proposed objectives.

Besides these questions, a teaching activity can also be inadequate due to problems in its internal organization: There may be lack of clear instructions, or inadequate interventions by the teacher, lack of correction regarding the student's performance, or even the complete absence of a relevant activity for the students. When such problems are frequent or acquire a great dimension, the school activities can become an extremely undesirable and demotivating practice for the student, generally producing disastrous effects and, obviously, deteriorating, sometimes altogether, the possible affective relations between the student and the school content. In addition to that, the cases of students' affective distancing from the whole school environment are not rare.

Lastly, it should be pointed out that a great deal of the affective load in the classroom is concentrated on the teaching activities, through the interpersonal relations between teachers and students: facial expressions, gazes, physical postures, verbal content, physical contact, proximity, tone of voice, receptiveness, instructions, corrections, etc., constitute aspects of the fabric of interpersonal relations that imply an enormous power of affective impact on the students, either positive or negative, depending on how these interactions are experienced. Hence, the relevance of such decisions is: After all, they concern the concrete ways in which the face-to-face relationships are experienced and perceived in class.

(5) The choice of assessment procedures:

One unanimous aspect which has been observed in the studies carried out by the Affection Group is that the traditional forms of assessing students have been pointed out as one of the main factors leading to the failure of the teaching-learning process, that is, for the affective distancing between the subject/student and the object/content. Assessment seems to become disastrous when its results are used against the students and, without doubt, when such relation is identified by them. This is the logic of the traditional assessment/evaluation process, whose objective is basically to rank students, identifying "the best and the worst". As all its foundations are centered in a conception of man derived from the liberal ideology, the basis of the capitalist system, according to which the differences in human capacity are innate, distributed in a Gaussian fashion among man.

In this perspective, teaching and learning are understood as independent processes: Teaching is the task of the teacher, learning is the duty of the student-and, if learning does not occur adequately, it is certainly due to some factor which is intrinsically related to the student. Leite and Kager (2009) highlight the devastating effects that the traditional assessment process can produce in the subject-object relations.

On the other hand, any alternative that replaces this model implies deep changes in the very conception of teaching and learning - including changes of ideological nature, involving the views of man, world, society, interpersonal relations and, of course, teaching and learning.

Luckesi (1984) proposes the concept of "diagnostic assessment", recognizing that, in a democratic society, the results of the assessment process must always be used in order to favor the student's learning process, as it completely alters the logic of the traditional process: If learning does not occur adequately, which can be detected by the assessment, then the teaching conditions must be reexamined, thus restoring the dialectic relationship between these two processes (teaching and learning are interdependent processes). Therefore, only when the assessment data are used as to favor the students can be one of the main conditions for a positive affective relationship between the student and the object of knowledge be established. Hence, this only occurs 
when the assessment results are used, for instance, to revise the teaching conditions or to support strategies that allow the students to adequately appropriate the content which has been developed.

It should be highlighted that such alternatives also imply the collective work developed by the institution faculty, that is, the teaching assessment policy cannot be a purely individual matter, to be decided by the teacher in isolation, but demands common guidelines, discussed and adopted by all professionals that work in the institution.

\section{A Final Remark}

Based on the discussion herein, it is possible to defend that affectivity is present in all decisions taken by the teacher in class, continuously producing positive or negative impacts on the students' subjectivity. It is, then, a founding factor in the relations that are established between the students and the educational content. The quality of the pedagogical mediation is, therefore, one of the main determinants of the quality of the bonds that will be established between the subjects/students and the objects/educational content.

That does not mean that we are defending a specific pedagogical proposal, but assuming that teaching conditions cannot be planned without taking into consideration the possible affective impacts they inevitably produce on students. In an educational perspective, this points to an educational environment which is absolutely committed to the students success in their learning process, and this can only be achieved by means of a pedagogical project which is planned and developed by the faculty collective who bear in mind the following: the students' learning process.

Based on these ideas, it is possible to envision the construction of an effectively democratic school, which allows the students to successfully appropriate the knowledge deemed essential for the full exercise of citizenship.

\section{References}

Almeida, A. R. S. (1997). A emoção e o professor: Um estudo à luz da teoria de Henri Wallon. Psicologia: Teoria e pesquisa, 13(2), 239-249.

Almeida, A. R. S. (1999). A emoção na sala de aula. Campinas: Papirus.

Amado, J., Freire, I., Carvalho, E., \& Anfré, M. J. (2009). O lugar da afectividade na relação pedagógica—contributos para a formação de professores. Sísifo. Revista de Ciências da Educação, 8, 75-86.

Arantes, V. A., \& Aquino, J. G. (Orgs.). (2003). Afetividade na Escola: Alternativas teóricas e práticas. São Paulo: Summus Editorial Ltda.

Ausubel, D. P. (1968). Educational psychology, a congnitive view. Nova York: Holt, Renehart \& Winston.

Bandura, A. (2005). The evolution of social cognitive theory. In K. G. Smith, \& M. A. Hitt (Eds.), Great minds in management (pp. 9-35). Oxford University Press.

Bogdan, R., \& Biklen, S. (1994). Investigação qualitativa em educação. (M. J. Alvarez, S. B. dos Santos, \& T. M. Baptista, Trans.). (Coleção Ciências da Educação). Porto: Porto Editora Ltda. (original published in 1991).

Bosch, P. van den (1998). A Filosofia e a Felicidade. São Paulo: Martins Fontes.

Casassus, J. (2003). La escuela y la (des)igualdad. Santiago do Chile: LOM.

Casassus, J. (2009). Fundamentos da Educação Emocional. Brasilia: Unesco e Liberlivro Editora.

Chauí, M. (2005). Espinosa —uma filosofia da liberdade (2 ed.). São Paulo: Editora Moderna Ltda.

Damásio, A. (2001). O erro de Dèscartes: Emoção, razão e cérebro humano. (D. Vicente., \& G. Segurado, Trans.). São Paulo: Cia. da Letras.

Damásio, A. (2003). Looking for Spinoza. San Diego, California: Harvest Book.

Dantas, H. (1992). Afetividade e a construção do sujeito na psicogenética de Wallon. In Y. de La Taille, H. Dantas, \& M. K. Oliveira (Orgs.), Piaget, Vygotsky e Wallon: Teorias psicogenéticas em discussão (pp. 85-98). São Paulo: Summus Editorial Ltda. 
Dér, L. C. S. (2004). A constituição da pessoa: A dimensão afetiva. In A. A. Mahoney, \& L. R. Almeida (Orgs.), A constituição da pessoa na proposta de Henri Wallon (pp. 61-75). São Paulo: Edições Loyola.

Engelman, A. (1978). Os Estados Subjetivos: Uma tentativa de classificação de seus relatos verbais. São Paulo: Ática.

Falcin, D. C. (2003). Afetividade e condições de ensino: A mediação docente e suas implicações na relação sujeito-objeto. Trabalho de Conclusão de Curso. Faculdade de Educação, Universidade Estadual de Campinas, Campinas, SP, Brasil.

Figueiredo, L. C. (1992). A Invenção do Psicológico: Quatro séculos de subjetividade. 1500-1900. (Coleção Linhas de Fuga). São Paulo: EDUC/Escuta.

Franco, A. F. (2009). O mito da autoestima na aprendizagem escolar. Psicologia Escolar e Educacional, 13(2), 325-332.

Giles, T. R. (1993). Dicionários de Filosofia: Termos e filósofos. São Paulo: EPU.

Leite, S. A. da S., \& Tassoni, E. C. M. (2002). A afetividade em sala de aula: As condições de ensino e a mediação do professor. In R. Azzi, \& A. M. Sadalla (Orgs.), Psicologia e Formação Docente (pp. 113-141). São Paulo: Casa do Psicólogo.

Leite, S. A. da S., \& Tagliaferro, A. R. (2005). A afetividade na sala de aula: Um professor inesquecível. Psicologia Escolar e Educacional, 9(2), 247-260.

Leite, S. A. da S. (Org.). (2006). Afetividade e práticas pedagógicas. São Paulo: Casa do Psicólogo.

Leite, S. A. da S., \& Colombo, F. A. (2006). A voz do sujeito como fonte primária na pesquisa qualitativa: A autoscopia e as entrevistas recorrentes. In S. G. Pimenta, E. Ghedin, \& M. A. R. S. Franco (Orgs.), Pesquisa em Educação: Alternativas investigativas com objetos complexos (pp. 117-136). São Paulo: Edições Loyola.

Leite, S. A. da S., \& Falcin, D. C. (2006). O professor inesquecível: Afetividade nas práticas pedagógicas. In M. T. C. Souza, \& V. S. R. Bussab (Orgs.). Razão e Emoção: Diálogos em construção (pp. 213-254). São Paulo: Casa do Psicólogo.

Leite, S. A. da S., \& Tassoni, E. C. M. (2007). Afetividade e Ensino. In E. T. Silva (Org.), Alfabetização no Brasil—questões e provocações da atualidade (pp. 113-137). Campinas: Autores Associados.

Leite, S. A. da S., \& Kager, S. (2009). Efeitos aversivos das práticas de avaliação da aprendizagem escolar. Ensaio-avaliação e políticas públicas em Educação, 17(62), 109-134.

Luckesi, C. C. (1984). Avaliação Educacional Escolar: Para além do autoritarismo. Tecnologia Educacional, 61, 6-15.

Ludke, M., \& André, M. E. D. (1986). Pesquisa em Educação: Abordagens qualitativas. São Paulo: EPU.

Mahoney, A. A. (1993). Emoção e ação pedagógica na infância: Contribuições da psicologia humanista. Temas em Psicologia. Sociedade Brasileira de Psicologia, 1(3), 67-72.

Mahoney, A. A. (2004). A constituição da pessoa: Desenvolvimento e aprendizagem. In A. A. Mahoney, \& L. R. Almeida (Orgs.), A constituição da pessoa na proposta de Henri Wallon (pp. 13 -24). São Paulo: Edições Loyola.

Marcondes, D. (2000). Iniciação à história da Filosofia — dos pré-socráticos a Wittgenstein. Rio de Janeiro: Jorge Zaar Editor.

Oliveira, M. K. (1992). O problema da afetividade em Vygotsky. In Y. de La Taille, H. Dantas, \& M. K. Oliveira (Orgs.), Piaget, Vygotsky e Wallon: Teorias psicogenéticas em discussão (pp. 75-84). São Paulo: Summus Editorial Ltda.

Oliveira, M. K. (1993). Vygotsky-aprendizado e desenvolvimento, um processo sócio-histórico. São Paulo: Scipione.

Pinheiro, M. M. (1995). Emoção e afetividade no contexto da sala de aula: Concepções de professores e direções para o ensino. Dissertação de Mestrado. Pontifícia Universidade Católica de São Paulo, SP, Brasil.

Ribeiro, M. L., \& Jutras, F. (2006). Representações sociais de professores sobre afetividade. Estudos de Psicologia, 23(1), 39-45.

Ribeiro, M. L. (2010). A afetividade na relação educativa. Estudos de Psicologia, 27(3), 403-412.

Spinoza. (2009). Ética. (T. Tadeu, Trad.). São Paulo: Autêntica.

Tagliaferro, A. R. (2003). Meu professor inesquecivel: A construção de uma memória coletiva. Trabalho de Conclusão de Curso. Faculdade de Educação, Universidade Estadual de Campinas, Campinas, SP, Brasil.

Vasconcelos, M. S. (2004). Afetividade na escola: Alternativas teóricas e práticas. Educação e Sociedade, 25(87), 616-620.

Vygotsky, L. S. (1993). Pensamento e Linguagem. (J. L. Camargo, Trad.). São Paulo: Martins Fontes.

Vygotsky, L. S. (1998). O desenvolvimento psicológico na infância. (C. Beliner, Trad.). São Paulo: Martins Fontes.

Wallon, H. (1968). A evolução psicológica da criança. (C. Carvalho, Trad.). Lisboa: Edições 70.

Wallon, H. (1978). De l'act à la pensée. Paris: Flammarion. (Original published in 1942).

Wallon, H. (1995). As origens do caráter na criança. (H. D. de S. Pinto, Trad.). São Paulo: Nova Alexandria. 